\title{
Splenic hematoma in a patient with Plasmodium vivax malaria
}

\author{
Hematoma esplênico em um paciente \\ com malária por Plasmodium vivax
}

Marcus Vinícius Guimarães de Lacerda ${ }^{1,2,3}$, Sócrates Lote de Oliveira ${ }^{3}$ and Maria das Graças Costa Alecrim ${ }^{2,3}$

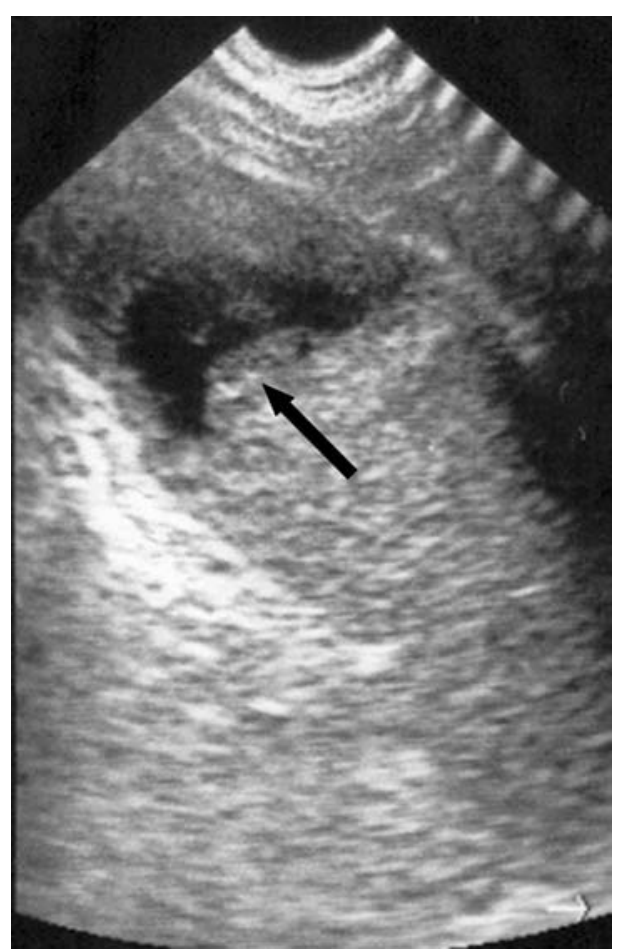

A

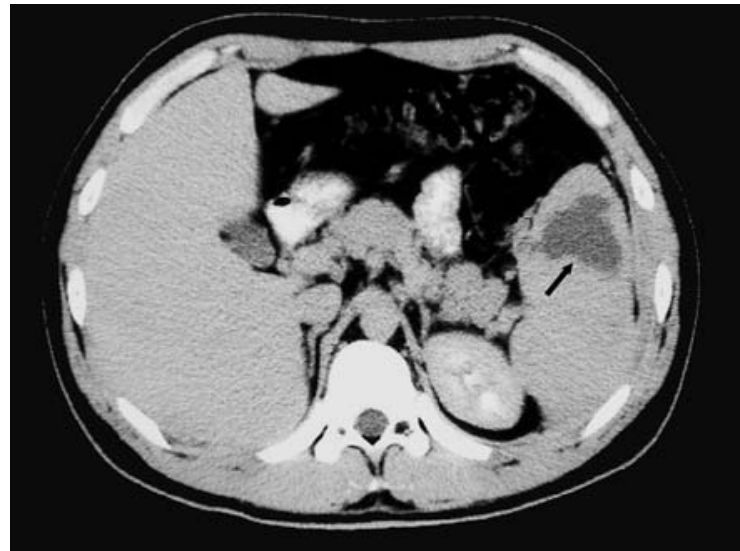

B

1. Gerência de Malária, Fundação de Medicina Tropical do Amazonas, Manaus, AM. 2. Universidade do Estado do Amazonas, Manaus, AM. 3. Centro Universitário Nilton Lins, Manaus, AM, Brasil.

Address to: Dr. Marcus Vinícius Guimarães de Lacerda. Gerência de Malária/FMTAM. Av. Pedro Teixeira 25, 69040-000 Manaus, AM, Brasil.

e-mail: marcuslacerda@uol.com.br

Recebido para publicação em 3/5/2006

Aceito em 12/1/2007 
A 23-year-old man presented with a 3-day history of fever, headache and chills. He lived in Manaus, which is an endemic area for malaria in the Western Brazilian Amazon region. Physical examination revealed enlargement of the spleen and laboratory data showed moderate anemia and thrombocytopenia. The routine thick blood smear was positive for Plasmodium vivax and the patient started treatment with chloroquine and primaquine. At the follow-up visit two weeks later, the patient was afebrile but was complaining of abdominal pain in the left hypochondrium. Abdominal ultrasound revealed splenomegaly with a large fluid collection in the lateral subcapsular area (Figure A) and several other smaller cystic collections in the parenchyma. An axial computed tomography scan showed an enlarged spleen and the same fluid collections inside the splenic parenchyma (Figure B). Two other probable, smaller collections were also seen in the splenic parenchyma. Strict bed rest was recommended for the patient and he did not develop any clinical signs of rupture of the spleen. The main splenic complications of Plasmodium infection are splenic hematoma, splenic rupture, hypersplenism, ectopic spleen, splenic torsion, splenic cysts and hyperreactive malarial spleen. Splenic rupture is generally the most common finding in Plasmodium vivax infections and is secondary to subcapsular hematomas. Nonsurgical management consists of observation for 7-14 days in the hospital, strict bed rest, and administration of fluids and blood derivatives as needed. Delayed rupture rarely occurs. When last seen one month later, the patient had recovered from the abdominal pain. Ultrasound showed a normal-sized spleen with some scattered small cystic lesions.

0 paciente de 23 anos de idade iniciou com história de três dias de febre, cefaléia e calafrios. Ele habitava em Manaus, uma área endêmica para malária, na Amazônia Ocidental Brasileira. 0 exame físico revelou aumento do baço e os dados laboratoriais mostraram anemia moderada e plaquetopenia. 0 exame da gota espessa de rotina foi positivo para Plasmodium vivax e o paciente iniciou tratamento com cloroquina e primaquina. Na visita de retorno duas semanas depois, o paciente estava afebril, mas se queixava de dor abdominal no hipocôndrio esquerdo. Uma ultra-sonografia abdominal revelou esplenomegalia com grande coleção líquida em topografia subcapsular lateral (Figura A) e várias outras coleções císticas menores no parênquima. A tomografia computadorizada axial mostrou baço aumentado de volume e as mesmas coleções no interior do parênquima esplênico (Figura B). Duas outras prováveis coleções menores também foram vistas no parênquima esplênico. Repouso no leito foi recomendado a paciente e ele não desenvolveu qualquer sinal clínico de ruptura esplênica. As principais complicações esplênicas da infecção por Plasmodium são o hematoma esplênico, ruptura esplênica, hiperesplenismo, baço ectópico, torção esplênica, cistos esplênicos e baço hiper-reativo da malária. Geralmente a ruptura esplênica é mais comum em infecções pelo Plasmodium vivax e é secundária aos hematomas subcapsulares. A conduta não-operatória consiste de observação por 7-14 dias em ambiente hospitalar, repouso no leito e administração de líquidos e hemoderivados, quando necessário. A ruptura tardia raramente acontece. Quando visto pela última vez, um mês depois, o paciente havia se recuperado da dor abdominal. A ultra-sonografia mostrou baço de tamanho normal com algumas pequenas lesões císticas espalhadas.

\section{REFERENCES}

1. Muniz-Junqueira MI, Moraes MA, Marsden PD. Reduction of spleen size in a child with hyperreactive malarious splenomegaly (HMS) treated outside the Brazilian endemic area of malaria with only one course of quinine. Revista da Sociedade Brasileira de Medicina Tropical 25: 257-259, 1992.

2. Ozsoy MF, Oncul O, Pekkafali K, Pahsa A, Yenen OS. Splenic complications in malaria: report of two cases from Turkey. Journal of Medical Microbiology 53: 1255-1258, 2004.

3. Zingman BS, Viner BL. Splenic complications in malaria: case report and review. Clinical Infectious Diseases 16: 223-232, 1993. 